The Federal Reserve BanK of Kansas City Research Working Papers

Global Tax Policy and the Synchronization of Business Cycles

Nicholas Sly and Caroline Weber August 2015 RWP 15-07 


\title{
Global Tax Policy and the Synchronization of Business Cycles
}

\author{
Nicholas Sly \\ Federal Reserve Bank of Kansas City, \\ University of Oregon and CESifo \\ and \\ Caroline Weber \\ University of Oregon * \\ August 2015
}

\begin{abstract}
Using a 30-year panel of quarterly GDP fluctuations from of a broad set of countries, we demonstrate that the signing of a bilateral tax treaty increases the comovement of treaty partners' business cycles by $1 / 2$ a standard deviation. This effect of fiscal policy is as large as the effect of trade linkages on comovement, and stronger than the effects of several other common financial and investment linkages. We also show that bilateral tax treaties increase comovement in shocks to nations' GDP trends, demonstrating the permanent effects of coordination on fiscal policy rules. We estimate trend and business cycle components of nations' output series using an unobserved-components model in order to measure comovement between countries, and then estimate the impact of tax treaties using generalized estimating equations.
\end{abstract}

JEL Classificaitons: H32, H87, F42, E62

${ }^{*}$ The views expressed herein are those of the authors and do not reflect the views of the Federal Reserve Bank of Kansas City or the Federal Reserve System. Much of the work on this project was conducted while Nicholas Sly was visiting CESifo, and he would like to thank the institute for its generous support. We would also like to thank Jeremy Piger for assistance at early stages. We have benefited from conversations with Céline Azémar, Steve Bond, Ron Davies, Peter Egger, Tim Goodspeed, Makoto Hasagawa, Jim Hines, Jean Imbs, Steven Lehrer, Joel Slemrod, Jeffrey Smith and Silvana Tenreyro, as well as conference participants at the National Tax Association meetings, International Institute of Public Finance Congress and Banque de France as well as seminar participants at Oxford University, CESifo, Paris School of Economics, University of Michigan and Queens University. Thanks to Laura Kawano and Joel Slemrod for generously providing corporate tax rate data. Also, we wish to acknowledge the very capable research assistance provided by Erin Weld. We are grateful to the University of Oregon Foundation for providing funds to purchase data on bilateral tax treaties from Thomas Reuters. All remaining errors are the responsibility of the authors. corresponding author: email - nick.sly@kc.frb.org, ph - 800-333-1010 
Economic shocks often cross borders generating comovement in nations' business cycles over time. For many countries, a significant portion of the fluctuations in their own GDP series are the result of shocks that originate abroad (Kose et al., 2003, 2008). Perhaps not surprisingly, comovement in output is known to be much stronger among countries with close economic ties. Here we highlight the fact that international fiscal policy agreements between countries are an important avenue by which national economies become more integrated. Bilateral tax treaties (BTTs) are prominent fiscal policy instruments that raise the incentives of firms to invest and operate in foreign countries, thereby opening a channel for transmission of output shocks. Recognizing the potential of BTTs to affect cross-border investment and production activities, our purpose here is to examine empirically how fiscal policy coordination affects comovement between countries' GDP series. We find that for a broad set of nations, the linkages created by these international tax agreements substantially increase comovement between nations' output fluctuations over time.

BTTs are among the most common tools to coordinate tax policies across countries. There are upwards of 2,500 tax treaties in force worldwide, including countries at various levels of development and from several regions of the world (Easson, 2000). Despite their ubiquity, the potential impact of BTTs at aggregate levels is still uncertain; recently the deputy director of the IMF Fiscal Affairs Department has questioned whether or not the IMF should advise nations to sign treaties at all, particularly developing nations. (Keen, 2014). Evidence on the potential for BTTs to facilitate the transmission of aggregate output shocks is of first-order importance to this debate.

The intended purpose of BTTs is to coordinate tax rules across countries in a manner that reduces the incidence of double-taxation of cross-border investments and foreign-earned incomes. One important consequence of these agreements is an increase in cross-border investment by multinational firms, and an increase in production by the foreign affiliates of these firms, which opens a channel for the transmission of output shocks across countries. Indeed, Davies et al. (2009) show that the entry rate of new multinational enterprises rises sharply once a new BTT enters into force. Importantly, Kleinert et al. (2014) show that the presence of foreign affiliates in a host country raises its output comovement with the nation from which the multinational firm originates. ${ }^{1}$ Cravino \&

\footnotetext{
${ }^{1}$ Moreover, they find that the effect that the presence multinational firms has on comovement in stronger when firms transfer intangible assets (such as patents, licenses or other technologies) to their foreign affiliates. These are precisely the assets that are most sensitive to the implementation of a BTT (c.f., Blonigen et al. (2014)), thereby raising the potential for such tax agreement to allow output shocks to be transmitted abroad.
} 
Levchenko (2014) confirm the quantitative importance of multinational firms in transmitting output shocks across borders. ${ }^{2}$ In addition to increased entry of new foreign affiliates, Blonigen et al. (2014) find evidence of increases in production by existing foreign affiliates once a treaty is signed with the parent company's home country. This fact is important here, as Burstein et al. (2008) show that such production sharing activities across countries also raises GDP comovement between nations. Beyond the tax treatment of cross-border investment production activities, BTTs also define rules over what types of establishments and incomes constitute the tax base within each jurisdiction, and even incorporate rules for the taxation of income earned from the shipping of goods between countries. Each of these provisions also impact the incentives to engage in international economic activities, and thereby can affect the transmission of economic shocks across borders. Our goal is to empirically assess the consequences of the various provisions within BTTs on GDP comovement between nations.

Although BTTs include a variety of different provisions, the specific rules adopted by each pair of countries after signing a BTT are relatively harmonized according to model treaties available from the OECD \& UN. Empirically, this harmonization across treaties provides a similarity in treatment that allows us to study how changes in fiscal policy influence comovement patterns for a broad set of countries. We exploit changes in treaty status within a panel of 210 country-pairs over a thirty-year time period (1980-2010), and estimate their effects on GDP comovement using both parametric and non-parametric techniques.

Our parametric strategy estimates the effect of a new BTT on comovement using generalized estimating equations (GEE). The GEE methodology builds from Papke \& Wooldridge (2008) and accounts for the fact that GDP comovement, measured as the correlation in aggregate output shocks between two countries over a decade, is a bounded variable between -1 and 1 . The empirical strategy permits the inclusion of correlated random effects, which allows us to control for unobserved timeinvariant country-pair effects. Hence, we identify the effects of BTTs via differences-in-differences, using changes in comovement across time within country-pairs that switch treaty status during the sample period. This eliminates concerns about the selection of countries into treaty status

\footnotetext{
${ }^{2}$ They document the large proportion of aggregate production that takes place within multinational enterprises, and then provide evidence that the share of total aggregate productivity shocks that is transmitted across countries by multinational firms is non-negligible, with the effect being much larger among more integrated countries.
} 
contaminating our estimates. ${ }^{3}$ Our strategy also permits the inclusion of time period-specific effects, which account for common shocks across countries. Another concern is the potential for reverse causality; however prior evidence confirms that cross-border investment activities increase only after the BTTs enter into force (Blonigen et al., 2014). The GEE method is new to this literature and applicable whenever the correlation between aggregate shocks is used as the dependent variable. ${ }^{4}$

Using the GEE strategy, we find that when a new BTT enters into force, it raises observed business cycle comovement by $1 / 2$ a standard deviation. This effect is quantitatively as important as the role of trade linkages in facilitating the transmission of shocks, is larger than the effect other common financial and investment policies, and is in sharp contrast with the lack of impact of currency union membership on cyclical comovement. ${ }^{5}$ We also find that BTTs have a positive impact on the comovement between shocks to the trend components of nations' GDP series, highlighting the permanent economic effects of fiscal policy coordination. Our results are robust to the method used to extract the cyclical and trend components of nations' GDP series, other potentially confounding features of country-pairs, as well as pair- and period- specific fixed effects. We also show that accounting for the boundedness of comovement is particularly important when using commonly implemented band-pass filter techniques to extract cyclical components of nations' GDP series, due to the fact that measured comovement levels frequently lie near the upper bound. Specifically, when using the popular HP filter (Hodrick \& Prescott, 1997), failing to account for the boundedness of measured comovement biases the effect of BTTs upward by half a standard deviation. In addition to our parametric methodology, we estimate kernel densities of comovement to show that the entire distribution of observed correlations in cyclical output shocks shifts symmetrically in response to the signing of a BTT, which suggests that a country's prior level of comovement does not play a role in their response to the introduction of a BTT.

\footnotetext{
${ }^{3}$ Using GEE with correlated random effects instead of a fixed effects fractional logit or probit model allows us to avoid the incidental parameters problem that commonly plagues estimation of these models (Papke \& Wooldridge, 2008), particularly in settings with a small time dimension (e.g. Fernández-Val, 2009) - as is the case with our three observed decade-long comovement periods.

${ }^{4}$ For example, identifying the determinants of correlation between output and government tax revenues is important in public finance literature, as the cyclicality of tax revenues can generate deadweight loss (see Seegert (2012) for example). In the finance literature, the comovement between stock exchanges across countries is of substantial interest (e.g., Karolyi \& Stulz (1996)), as is the well-known Fisher Effect, which describes comovement between asset returns and inflation (e.g., Boudoukh et al. (1994)). Also, a large macroeconomic literature is devoted to studying comovement between country aggregates besides output, such as consumption and investment.

${ }^{5}$ Baxter \& Kouparitsas (2005) also demonstrate that currency union membership does not have a robust impact on cyclical comovement once accounting for trade flows and other key country characteristics.
} 
The next section discusses the related comovement literature. Section 2 provides details about the empirical strategies we use to identify the impact of fiscal policy coordination. Section 3 discusses the methods we use to measure GDP comovement across countries, and lists data sources. In section 4 we present the the empirical results. The final section concludes.

\section{Comovement Literature}

Previous studies of the determinants of GDP comovement have focused primarily on commercial, industrial, or financial linkages between countries. The seminal analysis in Frankel \& Rose (1998) considers a large panel of country-pairs and finds that stronger trade linkages between countries generate greater degrees of comovement; see also Baxter \& Kouparitsas (2005), Burstein et al. (2008), Levchenko \& di Giovanni (2010), Clark \& van Wincoop (2001) and Blonigen et al. (2014).

In addition to trade flows, Imbs \& Wacziarg (2003) demonstrate that the similarity in industry specialization across countries is associated with greater comovement. Kose et al. (2003) also find that average levels of comovement vary across country-pairs according to their stage of development. Several studies, beginning with Rose \& Engel (2002), have argued that currency union membership leads to more synchronized business cycles. Ours is the first study to consider the impact of fiscal policy on the comovement of nations' output overtime.

It is worth emphasizing that our analysis examines how coordinated fiscal policy actions impact the relationship between output shocks across countries, which is distinct from the literature on the transmission of fiscal shocks across borders. This literature focuses on how changes in government deficit spending or tax rates within one country may impact the corresponding sovereign debt/spending abroad. The classic treatment of this issue is Frenkel \& Razin (1986), with more recent studies available in Corsetti \& Müller (2006), Corsetti et al. (2011), and Feyrer \& Shambaugh (2012), among others. Likewise, our focus on output shocks in nations' GDP series is distinct from transmission of financial shocks, such that default in government bonds within one country leads to financial instability elsewhere; see for example Guerrieri et al. (2012) and Claessens \& Forbesi (2001). 


\section{Empirical Strategy}

In this section, we describe our empirical strategies used to estimate the effect BTTs on GDP comovement. Our baseline specification is the simple linear empirical model used throughout the comovement literature. Second, we present the GEE empirical strategy that specifically accommodates the fact that BTTs must have non-linear effects because comovement is a bounded outcome. Third, we estimate the effects of fiscal policy coordination non-parametrically, and present kernel density estimates for observations that differ according to treaty status and time period.

\subsection{Baseline Model}

Our baseline specification is the standard model taken from the literature:

$$
\rho_{i j T}=\alpha+\beta \text { Treaty }_{i j T}+X_{i j T} \Gamma+\phi_{T}+\psi_{i j}+\epsilon_{i j T},
$$

where $\rho_{i j T}$ is the correlation between shocks in the quarterly GDP series of countries $i$ and $j$ during time period $T$, the variable Treaty $_{i j T}$ is an indicator for whether the country-pair $i j$ has a BTT in force during period $T$, the vector $X_{i j T}$ is a set of control variables, $\phi_{T}$ is a period-specific effect, and the term $\psi_{i j}$ is a country-pair fixed effect. The majority of the literature is focused solely on comovement of shocks at business cyclical frequencies, however the broad set of countries in our sample exhibit different cyclical and trend patterns within their GDP series. (See Morley et al. (2003), and Aguiar \& Gopinath (2007).) Hence, we present results for both the comovement of cyclical output and comovement of shocks to trend levels of output.

In addition to fiscal policy rules, there are several cofactors that we wish to control for when identifying the effect of fiscal policy coordination. The set of control variables included in $X_{i j T}$ are drawn from the previous comovement literature. The seminal paper by Frankel \& Rose (1998) demonstrates that trade flows between countries are associated with greater degrees of GDP comovement. ${ }^{6}$ In addition to trade flows, Imbs \& Wacziarg (2003) show that similarity in industry specialization across countries influences GDP comovement between countries. While our countrypair fixed effects partially capture such features, Imbs (2004) estimates a model with measures of differences in income to indicate potential synchronization between countries; we include this

\footnotetext{
${ }^{6}$ See also Baxter \& Kouparitsas (2005), Levchenko \& di Giovanni (2010), and Blonigen et al. (2014).
} 
measure as well. Rose \& Engel (2002) argue that nations within a currency union exhibit stronger comovement in cyclical output. We include an indicator variable, $C U_{i j T}$, that equals one if countrypair $i j$ belongs to a currency union during period T. Finally, Devereux \& Mansoorian (1992) show that coordinated changes in tax rates between nations impact relative GDP growth rates, and hence may influence their comovement relationship. To capture this, we include a measure of the absolute value of the difference in (top) corporate tax rates.

The evidence of period-specific comovement patterns in Kose et al. (2008) and Kose et al. (2012), and differences in international common shocks across decades documented by Stock \& Watson (2005) suggest that the empirical model should include period-specific effects, $\phi_{T}$. Average levels of comovement typically vary across country-pairs; see Kose et al. (2003). Moreover, the propensity to sign a tax treaty can differ according to unobserved country-pair characteristics. ${ }^{7}$ For these reasons, we prefer specifications that include country-pair unobserved effects, $\psi_{i j}$.

\subsection{Generalized Estimating Equations}

The baseline model in equation (1) corresponds to the empirical strategy typically used when examining the determinants of business cycle comovement between countries. However, this linear model fails to account for the fact that output comovement is bounded for any pair of countries, such that $\rho_{i j T} \in[-1,1]$. Thus, these estimates are, at best, a first-order approximation of the effect of signing a BTT.

To address this issue, we present an empirical strategy that builds from the GEE approach developed in Papke \& Wooldridge (1996, 2008). We first transform measures of comovement into fractional response variables. Given that correlations in output shocks vary between -1 and 1 , we perform the following transformation:

$$
\tilde{\rho}_{i j T}=\frac{\rho_{i j T}}{2}+\frac{1}{2}
$$

If the correlation for a country-pair during any period is -1 , then $\tilde{\rho}_{i j T}=0$ and if the correlation for any country-pair during any period is 1 , then $\tilde{\rho}_{i j T}=1$. Moreover, $\tilde{\rho}_{i j T}$ varies continuously and monotonically according to $\rho_{i j T}$ within the unit interval.

\footnotetext{
${ }^{7}$ For example, Egger et al. (2006) argue that fixed endowments (e.g., capital stocks) may influence the propensity for countries to sign BTTs.
} 
We then estimate the effects of BTTs on (the transformed fractional response measure of) comovement using generalized estimating equations. Specifically,

$$
\tilde{\rho}_{i j T}=\Phi\left(\beta \text { Treaty }_{i j T}+X_{i j T} \Gamma+\psi_{i j}\right)+\xi_{i j T}
$$

where $\Phi(\cdot)$ is the standard normal cumulative distribution function. Following Papke \& Wooldridge (2008) we make two standard assumptions regarding the distributions of the unobserved effects, $\psi_{i j}$. First, we assume that, conditional on $\psi_{i j}$, the regressors Treaty ${ }_{i j T}$ and $X_{i j T}$ are strictly exogenous. This does not, however, rule out the possibility that treaty status may be correlated with unobserved country-pair effects. Instead, we only require that, conditional on pair-specific effects, our key regressors are uncorrelated with $\xi_{i j T}$.

Second, to obtain estimates of the average partial effect of BTTs, we need to specify the distribution function for the unobserved effects. Again following the approach in Papke \& Wooldridge (2008), we employ a Chamberlain-Mundlak device, and impose a conditional normality assumption. Specifically, the conditional distribution of the unobserved country-pair effects satisfies

$$
\psi_{i j} \mid\left(\text { Treaty }_{i j T}, X_{i j T}\right) \forall T \sim \operatorname{Normal}\left(\theta+\bar{X}_{i j}, \sigma^{2} \exp \left(\bar{X}_{i j} \lambda\right)\right)
$$

where $\bar{X}_{i j}$ is a vector of time averages of all covariates, $X_{i j T}$, within each country-pair. Specifying the standard error structure in this way allows for heteroskedasticity across country-pairs. This method is commonly referred to as correlated random effects. As with the baseline fixed effects model, the inclusion of correlated random effects implies that we identify the effects of BTTs in the GEE specification via differences-in-differences using changes in observed comovement across decades within country-pairs that switch treaty status during the sample period. Note that in a linear panel setting, fixed effects and correlated random effects yield the same estimates (Wooldridge, 2010). In this non-linear panel setting, using GEE with correlated random effects instead of a fixed effects fractional logit or probit model allows us to avoid the incidental parameters problem that commonly plagues estimation of non-linear fixed effects models (Papke \& Wooldridge, 2008).

We could also include the time average of treaty status within a country-pair, $\overline{\text { Treaty }}_{i j}$, into the specification of the unobserved effects in (4). This might be important if the time at which countries 
sign new BTTs is correlated with their typical level of comovement. We note however, that because over our sample BTTs are introduced and not eliminated within country-pairs, there is a strong mechanical multicollinearity between Treaty $_{i j T}$ and $\overline{\text { Treaty }}_{i j}$. Given this artificial multicollinearity

that is generated by the inclusion of $\overline{\text { Treaty }}_{i j}$ our preference is to omit it; regardless, we show below that our results are insensitive to whether or not the time average of treaty status is included and the coefficient on $\overline{\text { Treaty }}_{i j}$ is approximately zero.

\subsection{Threats to Identification}

As we think about the identification of the effect of signing a BTT on comovement, there are several possible threats to identification, which include: (1) selection, (2) omitted variable bias, and (3) reverse causality. In this section, we discuss each concern and why we do not expect the concern to be problematic in this context.

Certain country-pairs may be more likely to sign a BTT than others and these countries may have different comovement, on average, than other countries. Similarly, perhaps the choice of when to sign a BTT is correlated with the country-pairs' average level of comovement. To the extent that the relationship between a country-pairs' propensity to sign a treaty and their comovement is constant over time, this would be captured by our fixed effects strategy in the linear model and our correlated random effects strategy in the GEE model. Given that we find the coefficient on $\overline{\text { Treaty }}_{i j}$ is approximately zero in the GEE model, we conclude this concern is not relevant in our data. If this relationship is time-varying, we would expect to capture at least some of this selection in the covariates we include; we will show in the empirical section below that our estimates our invariant to the inclusion of covariates once fixed effects or correlated random effects are included in the specification. Both of these results provide evidence that selection of certain countries into signing a BTT is not biasing our estimates.

Related to the last concern, we may be concerned about omitted variable bias. We have included the covariates that we believe may be correlated with the signing of a BTT and with comovement. However, there may be some covariates that are important but have been excluded because we have no data on these factors. The fact that we will show that our estimates do not change when we add covariates once fixed effects or correlated random effects are included mitigates concerns about omitted variable bias because these omitted variables would have to be correlated with the 
signing of BTTs and affect comovement, yet be uncorrelated with all the covariates we included, such as other trade and investment agreements, trade flows and fixed country characteristics, which is unlikely.

Lastly, we might be concerned about reverse causality, whereby countries implement treaties only after they experience episodes of positive comovement. If nations systematically sign BTTs after periods of increased investment, and this greater investment within a country-pair also leads to increased business cycle comovement, then one would spuriously attribute increased comovement to the effects of tax treaties. However, prior evidence assuages these concerns. Blonigen et al. (2014) show that investment by new multinational enterprises and production activities of existing affiliates rises only after a BTTs are in effect. Similarly, Davies et al. (2009) find that the entry rate of new foreign affiliates rises only after BTTs enter into effect. More directly, Chisik \& Davies (2004) provide evidence that BTTs reduce withholding rates, which subsequently incentivizes cross-border investment after the BTTs enters into effect. In other words, increased investment within countrypairs is the result of new BTTs, rather than new treaties being signed only after investment rises. Thus we are confident that observed fiscal policy changes lead to increased cross-border economic activities, and subsequently impact GDP comovement, and not the other way around.

This discussion on reverse causality raises the question why we would not empirically examine the mechanism by which BTTs first open a channel for the transmission of economic shocks in this paper. The impact of BTTs on cross-border investment activities has been established for specific countries from which there is information about destination-specific flows of foreign direct investment (FDI) and the opening of new foreign affiliates. (Davies et al., 2009; Blonigen et al., 2014) However, for our purposes, we would require that one could observe cross-border investment flows specific to country-pairs and the opening of new foreign affiliates from each country of origin across all 210 country-pairs in our sample. While information on aggregate foreign direct investment (FDI) stocks and flows are available for a few individual countries, information on FDI flows and foreign affiliate production are not generally available across all country-pairs in our sample. Moreover, even for the countries in which we observe bilateral investment activities, we do not observe a long-enough time span to measure and estimate the impacts on comovement. Without the ability to observe country-pair specific investment flows that result from BTTs, we focus on the reduced from specifications in (1) and (3) to identify in the impact of BTTs on the comovement in 
nations' GDP series.

\subsection{Non-Parametric Estimation}

The GEE strategy described in the last section has several advantages over the baseline linear model in (1). It does however impose a specific functional form on the conditional expectation of comovement on BTTs (i.e., the standard normal). More importantly, the results of the parametric strategy may not fully reveal important heterogeneity, or even mask non-monotonicities in the effects of BTTs. For example, while countries in our sample exhibit positive comovement on average, there are several country-pairs and time periods for which we observe negative comovement. It is plausible that country-pairs that comove negatively prior to a BTT exhibit more negative comovement afterwards, while countries with positive comovement exhibit more positive comovement afterwards. To address such concerns, we estimate kernel densities of observed comovement by treaty status for all country-pairs who signed a treaty during 1980-2010. All of our estimates are obtained using an optimal bandwidth and the Epanechnikov kernel. We obtain similar results with more narrow definitions of bandwidth, and if we employ other common kernels. To evaluate the role of BTTs, we calculate Kolmogorov-Smirnov statistics to examine whether the conditional density functions of comovement relationships differ according to treaty status.

\section{Data and Measurement}

This section provides information about data sources and measurement of the key variables of interest. We first describe the methodology to measure GDP comovement between countries. Second, we provide details about the specific fiscal provisions within BTTs, as well as their economic impact on cross-border activities. Finally, this section describes data sources and measurement for all covariates.

\subsection{Comovement}

Measuring comovement between countries requires information about GDP series across countries, which we take from the International Financial Statistics, made available by the IMF. For 21 countries, we observe real quarterly output from 1980:Q1 to 2010:Q4. The set of countries in our 
sample corresponds to those studied extensively in previous analyses of comovement. ${ }^{8}$ By restricting ourselves to the post-1980 period, we observe quarterly fluctuations in output (as opposed to lower frequency annual GDP data) for a large set of country-pairs. ${ }^{9}$ The high frequency of the GDP data is important given the short duration of many business cycles; for example, annual data average out business cycle episodes lasting only a few quarters.

From the real GDP series for each country, we must estimate business cycles and shocks to aggregate output for each country; the correlation in these shocks represents the level of comovement for any country-pair. The existing literature that examines comovement has taken multiple approaches to measure the business cycle component of real GDP, including deterministic detrending (linear or quadratic), the band-pass filters of Hodrick \& Prescott (1997) and Baxter \& King (1999), and statistical models that specify separately the distinct trend and cyclical components of real GDP. Deterministic detrending methods, which appeared early in the literature, are unnecessarily ad hoc, and do not flexibly allow country-specific trends to shift during the sample period. Measures of business cycles obtained from band-pass filters can also be problematic, given that they are particularly sensitive to the presence of unit-roots in countries' output series. ${ }^{10}$ Band-pass filters also require that we arbitrarily specify the frequency domain in which cyclical shocks occur. Given these limitations, we use measures of comovement obtained by estimating the business cycle and trend components in real GDP using an unobserved-components (UC) model, which is a common long-used tool for business cycle measurement. ${ }^{11}$ As shown in Section 4.5, all our results are maintained if we adopt measures of comovement constructed from estimates obtained from standard band-pass filters.

The UC framework divides $\log$ real GDP for country $i$ at date $t$, denoted $y_{i, t}$, additively into trend $\left(\tau_{i, t}\right)$ and cyclical $\left(c_{i, t}\right)$ components:

$$
y_{i, t}=\tau_{i, t}+c_{i, t}
$$

\footnotetext{
${ }^{8}$ The countries in our sample are Australia, Austria, Belgium, Canada, Denmark, Finland, France, Germany, Italy, Japan, Korea, Mexico, Netherlands, New Zealand, Norway, Portugal, Spain, Sweden, Switzerland, United Kingdom and United States.

${ }^{9}$ New Zealand is a slight exception in that we do not observe the real GDP series until mid 1982.

${ }^{10}$ If real GDP contains a unit root, band-pass filters will both produce a measure of the cyclical component that is partially influenced by shocks to the stochastic trend. As an example of this, Cogley \& Nason (1995) and Murray (2003) demonstrate that if real GDP is itself a random walk, band-pass filters generate a cyclical component. In the literature, this phenomenon is commonly known as a "spurious cycle." See, e.g., Cogley (2001) and Pedersen (2001).

${ }^{11}$ Early examples implementing the UC framework include Harvey (1985), Watson (1986), and Clark (1987).
} 
The trend component is specified as a random walk process, while the cyclical component follows a covariance stationary autoregressive (AR) process. Specifically, $\tau_{i, t}=\mu_{i}+\tau_{i, t-1}+v_{i, t}$, and $\phi_{i}(L) c_{i, t}=\epsilon_{i, t}$, where $\phi_{i}(L)$ is a $p^{t h}$ order lag polynomial with all roots outside the complex unit circle, $v_{i, t} \sim$ i.i.d. $N\left(0, \sigma_{v_{i}}^{2}\right)$, and $\epsilon_{i, t} \sim$ i.i.d. $N\left(0, \sigma_{\epsilon_{i}}^{2}\right)$. Consistent with the existing literature on business cycle measurement with UC models, we make the assumption of independence between trend and cyclical shocks, such that $\sigma_{v_{i}, \epsilon_{i}}=0 .{ }^{12}$ The model in equation (5) is estimated via maximum likelihood, and estimates of the unobserved trend and cycle components are constructed using the Kalman Filter. ${ }^{13}$

Finally, for each country-pair in our sample, we measure comovement as the correlation in the cyclical fluctuations in outputs obtained from the estimates in equation (5). The correlation between cyclical fluctuations in countries $i$ and $j$ over period $T$ is given by

$$
\rho_{i j T}^{c}=\operatorname{corr}_{T}\left(\widehat{c}_{i, t}, \widehat{c}_{j, t}\right)
$$

where $\operatorname{corr}_{T}(\cdot)$ is the correlation coefficient measured using data during period $T$, and $\widehat{c}_{i, t}$ and $\widehat{c}_{j, t}$ represent the Kalman filtered estimates of the business cycle component for countries $i$ and $j$.

There is substantial evidence in the existing literature that both the business cycle and trend components account for a substantial portion of quarterly fluctuations in international real GDP growth series; see, e.g., Cogley (1990), Morley et al. (2003), and Aguiar \& Gopinath (2007). Furthermore, Blonigen et al. (2014) demonstrates that comovement in trends versus cycles can have opposite relationships with key country-pair characteristics. Thus we are also concerned with how BTTs influence comovement in shocks to nations' output trends. The correlation between trend shocks in countries $i$ and $j$ over period $T$ is given by:

$$
\rho_{i j d}^{\tau}=\operatorname{corr}_{d}\left(\widehat{v}_{i, t}, \widehat{v}_{j, t}\right)
$$

\footnotetext{
${ }^{12}$ See, e.g., Harvey (1985), Clark (1987) and Harvey \& Jaeger (1993).

${ }^{13}$ The AR model for the trend component described above implies a constant average growth rate for the trend component of real GDP. Generally, we relax this restriction, and for each country estimate an AR model which allows for structural breaks in the series over time. This break date is estimated along with the other parameters of the model via maximum likelihood, assuming that the break date does not occur in the first or last $20 \%$ of the sample period. We select the estimates for each country by choosing the model that minimizes the Schwarz Information Criterion.
} 
where $\widehat{v}_{i, t}$ and $\widehat{v}_{j, t}$ are the Kalman filtered estimates of shocks to the trend components for $i$ and $j$.

\subsection{Bilateral Tax Treaties}

There are several reasons to focus our analysis on BTTs as the fiscal policy instrument of interest. First, they are among the most common, and hence most relevant, international fiscal agreements between nations. Second, the fact that they are bilateral accords is consistent with our measure of bilateral comovement between two counties' GDP series. Other international fiscal agreements that involve several countries simultaneously would be difficult to map into observations of bilateral comovement, and would create difficulties in interpreting estimated effects. Third, the specific provisions within BTTs are relatively harmonized due to the fact that they conform to model treaties from the OECD or UN. This fact mitigates concerns that the categorical variable indicating a treaty is in force masks substantial heterogeneity in treatment. Fourth, BTTs are permanent changes in fiscal policy, rather than being temporary changes in, say, sovereign debt levels, which likely vary at business cycle frequencies. This fact assuages endogeneity concerns due to coincident time variation between our key independent variable and comovement.

The provisions within BTTs provide meaningful changes to the tax treatment of international investment. Once enforced, the provisions within BTTs alter the tax base with regard to foreign earned income, taxation concerning licensing and royalty payments between related parties, and fundamental issues about which economic agents qualify as 'residents' subject to taxation in each jurisdiction. In addition to changes in the tax base, BTTs consequently reduce withholding rates (Chisik \& Davies, 2004). As a result, the implementation of BTTs can lead to substantial reductions in the effective tax rate foreign-earned income in several countries.

BTTs also provide multinational corporations the right to challenge their determined tax liability with the Competent Authorities of each treaty partner if they believe they are being doubletaxed across the two nations. For example, provisions for Mutual Assistance Procedures (Article 25 of the OECD model treaty) allow the two contracting states (i.e., the tax agencies within each treaty partner) to consult with one another about the appropriate tax base to be used for determining liabilities in each nation. ${ }^{14}$ Even though most governments offer some form of direct tax

\footnotetext{
${ }^{14}$ In order to facilitate Competent Authority requests, BTTs also contain provisions that specify information sharing agreements between national tax agencies; without information sharing agreements each nation would not have the right to discuss a particular case with a foreign entity, precluding any ability to address the alleged double
} 
relief via credits or exemptions, complex licensing of intellectual property or trade in differentiated goods that have poorly defined transfer prices between parents and affiliates can generate substantial confusion about what is the appropriate level of income to levy taxes upon in each country. The availability of Mutual Assistance Procedures within BTTs reduces both compliance costs and effective tax rates, and thereby promotes international investment.

The evidence confirms that BTTs do have an economically meaningful impact on cross-border investment, and thereby create a channel by which international output shocks are transmitted across borders. First, Davies et al. (2009) and Blonigen et al. (2014) show that the entry rate of new multinational enterprises rises sharply once a new BTT enters into force, and Cravino \& Levchenko (2014) demonstrates that the presence of foreign affiliates raises output comovement between the host country and the the nation from which the multinational firm originates. Moreover, the effect of multinational firms' presence on comovement in larger when firms transfer intangible assets (such as patents, licenses or other technologies) to their foreign affiliates. (Kleinert et al., 2014). These are precisely the assets that are most sensitive to the implementation of a BTT (c.f., Blonigen et al. (2014)), thereby raising the potential for such tax agreement to allow output shocks to be transmitted abroad. Blonigen et al. (2014) also find substantial increases in foreign affiliate production once a treaty is signed with the parent company's home country, and Burstein et al. (2008) show such cross-border production sharing can also substantially increase GDP comovement between countries. Given that BTTs facilitate cross-border investment and production activities of multinational firms who themselves account for a large share of aggregate output and the transmission of shocks, the quantitative impact of a BTT on GDP comovement may be substantial.

The inclusion of country-pair effects into our empirical models implies that we identify the effects of BTTs by changes in comovement relationships within countries that switch treaty status. While specifying the model in this manner assuages some endogeneity concerns regarding treaty status across countries, it does raise issues with regard to specifying the period $T$ over which output correlations are measured. Consider two sets of country-pairs $i j$ and $k l$ for which we observe a new BTT signed during the sample period, but the date the treaties enter into force is different. The length of the pre-treaty period for country-pair $i j$ is not the same for pre-treaty period for pair $k l$, and likewise for the respective post-treaty periods. Hence, taking the naive approach of defining $T$ taxation. 
according to pre- and post- treaty periods would confound the empirical analysis by defining the BTT treatment asymmetrically across different country pairs. Moreover, countries that do not sign a new treaty during the sample period would have only one observation, while those that signed a treaty would have two observations. Neither of these features of the pre/post treaty definition of the comovement period are appropriate.

Our approach to defining comovement periods, $T$, is to select a period of time over which output correlations are calculated symmetrically across all country-pairs in the sample. Specifically, we set $T$ to be a decade, which in our sample generates three observed time periods within each country-pair (1980:Q1-1989:Q4, 1990:Q1-1999:Q4, and 2000:Q1-2010:Q4), and yields a balanced panel. There are several reasons to consider a decade-long time period. First, this time interval is consistent with prior literature on the determinants of GDP comovement, which aids comparability of our results. ${ }^{15}$ Second, Doyle \& Faust (2005) find structural breaks in time-series processes for international real GDP series that correspond roughly to traditional decade definitions. Thus, the decade-long period is plausibly the maximum length for which one can compute correlations without contamination from structural breaks. Third, Stock \& Watson (2005) show that international common shocks were much different across decade periods, leading to substantial differences in business cycle comovement among G7 countries over time. Using period-specific effects, $\phi_{T}$, that correspond to decades allows us to capture this feature. Fourth, measuring comovement over periods shorter than a decade-long time span reduces the number of observations available to estimate the actual link between nations business cycles, and increases the likelihood that observed comovement patterns are due to single business cycle episodes. ${ }^{16}$ Table 1 reports average decadelong comovement across all decades and country-pairs: average cyclical comovement is 0.248 and average trend comovement is 0.211 .

Instead of constructing a period of comovement as the dependent variable, one might consider regressing each country's quarterly cyclical shock on the interaction between the partner's corresponding cyclical shock and an indicator for whether or not a BTT is in place (while separately controlling for the partner's corresponding cyclical shock). This coefficient estimates how much

\footnotetext{
${ }^{15}$ See for example Frankel \& Rose (1998), Calderon et al. (2007), Kose et al. (2003) and Blonigen et al. (2014).

${ }^{16}$ Although the decade-long span is preferable, in an earlier working paper we examined comovement observed across a 8-year window and a 12-year window to verify that our results are not due to the selection of the comovement time-period, and find quantitatively similar results.
} 
more of a partner's shock is shared when a BTT is in place. This regression avoids the challenges associated with choosing a particular window and shows that window choice is not driving our results. Using this strategy, our estimates are approximately the same and remain significant at the one percent level. However, this is not our preferred specification because it is not straightforward to control for other determinants of comovement (e.g., trade) separate from their short-run correlation with cyclical shocks, nor to compare their estimated effects with prior literature.

Treaty status for each country-pair is taken from the actual treaty documents available in the International Bureau of Fiscal Documentation. As is standard when examining BTTs, we define treaty status based on the in force date, not the date that the treaty is signed; the signature dates of treaties are typically several year prior to their entry into force, due to institutional delays surrounding the ratification of the treaty by each country. Table A.1 in the appendix lists all the treaties between country-pairs that entered into force in our data set. Each treaty may have been in force for only part of the decade over which comovement is constructed, so we use the average treaty status over the decade (e.g., Treaty is 0.8 if the treaty is in force for 8 out of the 10 years in the decade under consideration). Our parametric results are almost identical quantitatively if we try other reasonable measures of treaty status, such as an indicator that is one if the treaty was in place more than five years and zero if it was in place for less. Note however, non-parametric estimation requires that the treaty variable is binary, precluding the possibility of using average treaty status to measure the BTTs variable. Thus, for the non-parametric exercise we consider a treaty in force between a country-pair $i j$ during the decade denoted by $T$ if the treaty is in force for half of the years $t \in T$.

\subsection{Covariates}

Information about bilateral trade flows come from the Direction of Trade Statistics reported by the IMF. We observe total imports and exports between country-pairs. Trade flows are expressed in real US dollars. As is standard in the comovement literature, we divide real trade flows by the sum of countries' GDP, so that the trade variable can be interpreted as a measure of openness. We divide the trade variable by 100 to improve exposition of the tables that follow. Annual population data come from the International Financial Statistics database which, combined with GDP data, provide us with a measure of GDP per capita. Both GDP and population are indexed so that 
they equal one in 2005:Q1. From this, we construct the absolute value of the average GDP per capita difference between each country and its partner across each decade. We use top marginal federal statutory corporate tax rate data from Kawano \& Slemrod (2012), which comes from the University of Michigan World Tax Database for years 1980-2002, and the OECD Tax Database for years 2003-2008. From this, we construct the absolute value of the average corporate tax rate difference between each country and its partner across each decade. Table 1 reports that the average (across all decades and country pairs) corporate tax rate difference between a country and its partner is 7.607 percentage points.

\section{Results}

Before turning to the regression results, we consider the properties of observed correlations in output shocks across our sample. Figure 1 plots the average decade-long comovement in cyclical and trend shocks to GDP across all country-pairs by quarter. For example, the comovement plotted for the first quarter of 1982 is the comovement from the first quarter of 1982 to the first quarter of 1992. After 2001, comovement is calculated as comovement from a given point in time through the end of the sample (2010 Q4).

Cyclical comovement patterns exhibit a stark U-shape over the 30 year sample period. The steady decline in the average cyclical comovement prior to the 2000s is consistent with the evidence in Doyle \& Faust (2005), while the sharp increase in average comovement in the latter part of the sample period corresponds with the global recession beginning in 2008. The U-shape pattern in cyclical comovement mitigates concerns about spurious results due to prior aggregate trends, where the incidence of BTTs has been rising steadily over time and the average differences in corporate tax rates have been falling steadily over time.

Prior to 1998, the average level of trend comovement is flat. After 1998, the decade-long correlation in output includes observations from the latest global recession. As a result there is a sharp increase in average trend comovement in the latter part of the sample. Again, the flat level of trend comovement in the early part of the sample assuages concerns about obtaining spurious estimates. When estimating the effects of BTTs on comovement below we are careful to control for the global recession period at the end of our sample. 


\subsection{Results from Baseline Model}

Table 2 examines the effect of a tax treaty on cyclical comovement by estimating our baseline specification as laid out in equation (1). This specification corresponds to prior studies of the determinants of comovement. The standard errors in Table 2, and all other estimates in the paper, allow for heteroskedasticity and are clustered at the country-pair level. ${ }^{17}$

Column (1) includes only decade fixed-effects and the covariate of interest - Treaty. It does not include country-pair fixed effects. The coefficient on Treaty is 0.277 and is significant at the one percent level. This means that signing a new BTT raises the correlation between the two countries' GDP cyclical fluctuations by 0.666 of a standard deviation in observed business cycle comovement. When covariates are added in Columns (2) and (3), the estimated effect of a BTT declines by about one-third. When fixed effects are included in Columns (4)-(6), the estimated effect of a BTT remains approximately the same as in Columns (2) and (3), although the standard errors almost double. The stability of the estimated impact of BTTs across specifications further assuages concerns that the signing of a BTT is endogenous to particular countries or periods in the sample.

The estimates in Column (5), which includes all covariates as well as country-pair and decade fixed effects across the entire sample period, are our preferred estimates in this linear response framework. The Treaty coefficient is 0.206 and is significant at the five percent level. This means that signing a new BTT raises the correlation between the two countries' GDP shocks by approximately $1 / 2$ of a standard deviation (0.495) in observed business cycle comovement. The economic magnitude of this effect is substantial. For the sake of comparison, the size of the effect of BTTs is slightly larger that that of trade linkages between countries, which are a well-known and often studied channel for the transmission of aggregate shocks. Specifically, a one-standard deviation increase in observed trade linkages also increases business cycle comovement by just under a third (0.289) of a standard deviation. Thus. the role of these fiscal policy instruments in linking nations business cycles in economically meaningful. To better interpret the size of this effect it is important to note that nations exhibit greater degrees of business cycle comovement if either (i) the time

\footnotetext{
${ }^{17}$ Clustering on the country-pair accounts for the plausible serial correlation in comovement within a country-pair across decades. Regardless, the standard errors that cluster on the country-pair are more conservative than those clustered at more aggregated levels, and so we report those.
} 
it takes for aggregate shocks to cross borders becomes less, or (ii) the magnitude of the nations' business cycle shocks becomes more similar. Recall that the dependent variable is the correlation in cyclical output shocks, not aggregate GDP levels. In other words, the result that a new BTT raises the correlation between the two countries' GDP fluctuations does not necessarily mean that their respective aggregate output levels change drastically. In this sense, the large magnitude of the estimated effect of BTTs is plausible and of similar magnitude to other previously studied determinants.

Column (6) provides an additional robustness check by excluding the 2000-2010 decade (and thus the global recession), and the estimated effect of BTTs remains the quantitatively similar: 0.230 without 2000 s as compared to 0.206 when looking across the whole sample. Given the lack of significance of the 2000's fixed effect, it is not surprising that the estimates are highly insensitive to this exclusion. The estimated effects of our control variables correspond to the results obtained in previous analyses. Differences in GDP per capita, which capture differences in the patterns of industry specialization between countries, are associated with lower comovement, consistent with the evidence in Imbs (2004) and Imbs \& Wacziarg (2003). The coefficient on the G7 indicator suggests that there are higher average levels of comovement among member nations, consistent with the evidence in Kose et al. (2003). Although there is a robust estimated effect of G7 membership, we prefer to allow for more general differences in comovement levels among countries, and include country-pair fixed effects, which subsume the G7 indicator variable.

As first documented by Frankel \& Rose (1998), trade linkages are associated with greater comovement. Consistent with previous work, in Columns (2) and (3) we find that countries that trade more intensively indeed exhibit greater levels of comovement. In the linear model, the role of trade linkages appears insignificant in Column (4) when country-pair fixed effects are included. Yet, once we also control for time period specific effects in Column (5) - our preferred specification - we confirm the stylized fact that trade has a significant positive effect on business cycle comovement. Table 2 also reports a positive estimated effect of currency union membership without country-pair effects (as in Rose \& Engel (2002)); yet once we control for fixed gravity variables using countrypair effects, currency union membership has a negative and only marginally significant effect on comovement (as shown by Baxter \& Kouparitsas (2005)). Devereux \& Mansoorian (1992) show that coordinated changes in tax rates can influence relative economic growth, and hence may influence 
comovement. As they argue, the impact of coordinated tax rates is ambiguous and depends, inter alia, on the (unobserved) intertemporal substitution elasticity and government spending on public versus private good. Hence, we have no prior about how coordinated tax rates might influence comovement. The evidence in the final columns of Table 2 reveals that changes in corporate tax rates within countries positively impact comovement of their business cycles.

\subsection{Results from GEE Model}

Table 3 examines the effect of a BTT on cyclical comovement by estimating the GEE specification as laid out in equation (3). This model addresses the fact that the dependent variable - comovement - is bounded between -1 and 1 . We begin by examining the same variant specifications considered in our baseline linear model. The coefficients reported in Table 3 are the estimated average partial effects, and the standard errors are again clustered at the country-pair level. Column (5) in Table 3 is directly comparable to our preferred estimate from Table 2: the corresponding estimate of the effect of signing a BTT from the GEE strategy implies that that signing a new BTT raises the correlation between the two countries' GDP cyclical fluctuations by 0.476 of a standard deviation in observed business cycle comovement, which is remarkably similar to our preferred estimate in the linear model (0.495), suggesting that the boundedness of the outcome variable does not significantly bias the estimates for Treaty in the linear model.

Note that Columns (4)-(8) of Table 3 estimate the GEE model with correlated random effects for unobserved country-pair characteristics, which is implemented according to equation (4) by the inclusion of time averages of all covariates. In Columns (4)-(5) we include the time average observation for treaty status $\overline{\text { Treaty }}_{i j}$, for which there a strong mechanical multicollinearity between it and Treaty $y_{i j T}$ due to the fact that, over our sample, BTTs are introduced and never eliminated. Regardless, the estimate in Column (5) is significant at the five percent level and an F-test reveals (i.e., the joint test of Treaty ${ }_{i j T}$ and $\overline{\text { Treaty }}_{i j}$ ) that the positive effect of BTTs is significant at the one-percent level. Moreover, the coefficient on $\overline{\text { Treaty }}_{i j}$ in Column (5) is -0.011 (p-value: 0.84) and Column (6) excludes $\overline{\text { Treaty }}_{i j}$ and shows that the coefficient on BTT remains the same, suggesting that the timing of treaty signings for country-pairs is indeed exogenous. ${ }^{18}$ Thus, Column (6) is our

\footnotetext{
${ }^{18}$ We also consider another alternative not reported in the table in which, in place of $\overline{\text { Treaty }}_{i j}$, we include an indicator for always having a treaty and another indicator for never signing a treaty. The coefficient on Treaty remains approximately the same, and the coefficients on these indicators are small and not statistically significant.
} 
preferred specification and we exclude $\overline{\text { Treaty }}_{i j}$ in all subsequent columns and tables that include correlated random effects unless otherwise noted.

The effect of trade in Column (6) of Table 3 is 0.139 and is significant at the five percent level. The coefficient implies that increasing trade by one standard deviation increases the correlation between the two countries' GDP series by 0.351 of a standard deviation in observed business cycle comovement. Again, the role of trade linkages is slightly smaller than the effect of BTTs, albeit with the same order of magnitude. The coefficient on corporate tax rate differences is 0.004 and significant at the five percent level in Column (6). This result emphasizes the fact that while coordinating tax rules via a BTT substantially increases comovement, synchronizing tax rates across countries does the opposite. This is not surprising as both increasing tax base coordination and decreasing tax rate coordination likely induce more investment abroad, thereby increasing the exposure of the domestic economy to foreign shocks.

In Column (7) we exclude the 2000s decade to address potential concerns that the outlying observations from the latest recession impact our estimates. Eliminating these observations, we continue to find a positive and significant effect of BTTs that corresponds closely in magnitude to the estimates from the entire sample period. In Column (8) of Table 3 we introduce additional intentional agreements into the GEE strategy that might also influence comovement relationships: bilateral investment treaties (BITs) and free trade agreements (FTAs). One might be concerned that the estimated effect of Treaty is actually capturing the propensity to sign agreements that integrate national economies, but it is the changes in economic activity associated with the other trade and investment accords that actually influence comovement. However the introduction of BITs and FTAs in Column (8) has almost no impact on the quantitative effect of Treaty, and the result remains significant at the one percent level. ${ }^{19}$ BITs and FTAs each appear to have a significant impact on business cycle comovement, but importantly these effects appear to be independent of the role of BTTs. ${ }^{20}$ While the negative coefficient on BITs may seem surprising, it is important to know that BITs were only signed during this period by Mexico and Korea, with

\footnotetext{
${ }^{19}$ The time averages of treaty status for BITs and FTAs $\left(\overline{B I T}_{i j}\right.$ and $\left.\overline{F T A}_{i j}\right)$ are excluded from this regression for the same reason as $\overline{\text { Treaty }}$ is excluded.

${ }^{20}$ The distinction between BITs and BTTs is explicit. For example, Article 21 of the US model bilateral investment treaty states "Nothing in this Treaty shall affect the rights and obligations of either Party under any tax convention. In the event of any inconsistency between this Treaty and any such convention, that convention shall prevail to the extent of the inconsistency."
} 
one exception. Both countries experienced major crises in the 1990's. If we re-estimate column (8) excluding the 1990's, the BIT estimate drops to zero and becomes highly insignificant, while the coefficient on Treaty remains almost identical.

The fact that the inclusion of covariates has little effect on our coefficient of interest - the coefficient experiences a highly insignificant decrease from 0.110 in Column (4) to 0.090 in Column (8) - mitigates concerns about additional omitted variable bias as these omitted variables would have to be correlated with the signing of BTTs and affect comovement, yet be uncorrelated with all the covariates we included, which is unlikely. The stability of the estimated effect of BTTs as we introduce covariates also eliminates further concerns of reverse causality from other country-pair characteristics. If increases in trade flows or the signing of other investment and trade agreements raise business cycle comovement, and also lead countries to sign tax agreements, then the estimated effect of BTTs would change substantially as we introduce these variable into the regression in Table 3. The stability of the estimated effect of BTTs to the inclusion of the other country-pair linkages confirms that such reverse causality is not contaminating our estimates.

\subsection{Trend Comovement}

For many countries, shocks to output trends constitute a sizable fraction of the total variation in GDP over time, and relevant to our purposes, it may also be the case that the transmission of output shocks differs between trend shocks and cyclical shocks. In Table 4 we examine the impact of BTTs on comovement of shocks to GDP trends. We continue to implement the GEE empirical strategy and report standard errors clustered at the country-pair level.

Columns (1) - (3) of Table 4 examine the effect of signing a BTT on the comovement of trend shocks without unobserved country-pair effects, while Columns (4)-(8) implement our preferred strategy and estimate the model with correlated random effects. The estimated impact of BTTs are remarkably stable across these columns with one exception - the estimate rises substantially in Column (2) when decade fixed effects are excluded. This reflects the fact that, unlike cyclical comovement, trend comovement is increasing over time as more treaties are signed (see Figure 1); without the decade effects, the estimates are biased upwards.

Our preferred estimates are in Column (6); the specification corresponds to our preferred specification estimating the response of cyclical comovement in Table 3. The estimate of Treaty is 0.026 
and is significant at the five percent level, which implies that signing a new BTT will increase the correlation of GDP trends between the two countries by 0.215 of a standard deviation. Although the estimated effect of BTTs on the comovement of trend shocks appears smaller than the $1 / 2$ standard deviation increase in cyclical comovement, this does not imply that the economic impact is smaller. Over the long-run, shocks to a nations' output trends can be quantitively more important in explaining the overall variation in their GDP series. Hence, despite the relatively smaller coefficient on the Treaty variable, the impact of BTTs on comovement in trend shocks within a particular decade is still economically substantial.

The decade fixed effects included in Column (6) of Table 4 are consistent with the pattern of trend comovement across time that was depicted in Figure 1. Trade linkages have a marginally significant and negative effect on trend comovement, which is consistent with the results in Blonigen et al. (2014). The coefficient on GDP per capita differences is -0.183 and significant at the one percent level. The coefficient on the corporate tax rate difference is negative and significant at the five percent level, which contrasts with its positive estimated impact on business cycle comovement. ${ }^{21}$ One surprising result is the positive and significant impact of currency union membership on trend comovement. The coefficient on currency union in Column (6) is 0.057 and is significant at the five percent level,whereas there is no robust impact on business cycle synchronization.

Column (8) adds FTAs and BITs. The addition of these variables has a negligible effect on the other estimated coefficients. We find that FTAs promote comovement in trend shocks, consistent with its positive impact of trade agreements on cyclical comovement. Likewise, members of the EU customs union exhibit stronger trend comovement on average. BITs have a near zero effect on trend comovement. Importantly, the effects of these other investment and trade agreements appear to be independent of the role of BTTs - the coefficient on BTTs only decreases by 0.005 with the inclusion of these variables. More generally, the fact that the inclusion of covariates has little effect on our coefficient of interest - the coefficient experiences a highly insignificant decrease from 0.035 in Column (4) to 0.021 in Column (8) - mitigates concerns about additional omitted variable bias as these omitted variables would have to be correlated with the signing of BTTs and affect

\footnotetext{
${ }^{21}$ The opposite effects of tax rate differences for comovement in trend shocks and business cycles may not be surprising given the result in Devereux \& Mansoorian (1992) that the effect of coordinated tax rates on relative economic growth depends on the intertemporal substitution elasticity, and hence the persistence with which macroeconomic shocks are perceived.
} 
comovement, yet be uncorrelated with all the covariates we have included, which seems unlikely.

\subsection{Heterogeneous Effects of BTTs}

Much of the prior literature on comovement has emphasized significant heterogeneity in both the propensity for different countries to comove, and the impacts of country characteristics in promoting the transmission of shocks across borders. For example, member nations of the G7 are known to exhibit stronger degrees of comovement relative to non-members (Kose et al. (2003)). Finally, there is prior evidence that the effects of several determinants of comovement across countries differs between G7 and non-G7 members; see Kose et al. (2008), Calderon et al. (2007) and Blonigen et al. (2014).

Besides the differences between G7 and non-G7 nations, there may also be important differences in the effects of BTTs across countries with different levels of initial comovement. BTTs may symmetrically raise the correlation between shocks to nations' GDP series. Alternatively, it may be the case that nations with negatively correlated business cycles have even more diametrically opposed cycles after treaties enter into force, while those with positive comovement have even more synchronized business cycle after signing a new BTT.

Recognizing these differences, in this section we examine the heterogeneous effects of BTTs by (i) examining sub-samples of country-pairs with and without G7 nations separately, and (ii) estimating kernel density estimates of cyclical and trend comovement over the entire distribution of observed comovement according to treaty status and time.

\subsubsection{Results by G7 Membership}

In Table 5, we estimate the effects of BTTs separately for country-pairs in which neither country is a member of the G7, and country-pairs for which one country is a member of the G7. Specification (1) includes only period-specific effects, while specification (2) introduces additional covariates and specification (3) is our preferred approach that includes all covariates, time-period effects, and country-pair correlated random effects. ${ }^{22}$

\footnotetext{
${ }^{22}$ Each G7 nation had a BTT in force with other members prior to the sample period, which precludes estimating the effects of BTTs within the G7 exclusively when correlated random effects are included. Note that when covariates are included, the specification is identical to those reported previously Table 3 Column (8); for the sake of brevity, we suppress the estimates of all control variables and focus on the role of BTTs.
} 
Row 1 of Table 5 reports the effect of BTTs on business cycle comovement from each specification separately for G7 and non-G7 membership. A striking pattern emerges: for nations outside the G7 there appears to be little robust effect of tax treaties, while country-pairs that include G7 nations realize significant increases in cyclical comovement once a new BTT enters into force. ${ }^{23}$ The greater efficacy of BTTs on cyclical comovement amongst the G7 nations mirrors the results found in previous studies regarding trade and financial integration; outside large industrial nations such financial or trade linkages appear to play little role in the transmission of business cycles (Calderon, Chong \& Stein, 2007). However, Row 2 of Table 5 demonstrates that to consider only cyclical shocks would ignore another important moment of GDP comovement: namely, the propensity to share trend shocks.

While BTTs seem to have no impact on business cycle comovement outside the G7, there appears to be a positive and significant impact on the comovement of trend shocks. Also in contrast to the results for cyclical comovement, the estimated effects of BTTs on trend comovement are an order of magnitude smaller for G7 pairs than for non-G7 nations, and indistinguishable from zero. These results highlight the importance of considering both cyclical comovement and comovement in shocks to output trends. While fiscal policy rules seem to impact nations differently, it would be an error to conclude that BTTs have no impact on the comovement of any subset of nations' output series. Rather, the effects of BTTs are realized at different moments of the GDP series for different sets of countries.

\subsubsection{Results from Non-Parametric Estimates}

In Figure 2 we present estimates of the kernel density of observed business cycle comovement separately across observations in which there is a treaty in force between countries for each decade, and observations for which there is not. ${ }^{24}$ We include only country-pairs that change treaty status during our sample period.

Our non-parametric estimates suggest that if cyclical comovement was negative before the BTT

\footnotetext{
${ }^{23}$ Splitting the sample according to G7 membership does reduce the power available to estimate the impact of BTTs. Still, in each specification the point estimate on BTT is an order of magnitude smaller for pairs outside the G7, suggesting that the insignificant impact is not simply due less efficient estimation.

${ }^{24}$ Note that as in the parametric estimation above, each country-pair has three observations included in the non-parametric estimation. Each of these observations within pairs will belong to different kernel density estimates according treaty status across time.
} 
was signed, the treaty decreases the degree of negative comovement, and if comovement was positive before the treaty was signed, it increases the degree of positive comovement. The center mass of the distribution of comovement in periods prior to the BTT is near zero, but increases after the treaty enters into force. Put another way, signing a BTT appears to increase cyclical comovement for any degree of prior comovement. This fact confirms that the results in the parametric models are not driven by outliers in the sample. More importantly, the broad ranging effects of BTTs across country-pairs and time speak directly to the efficacy of such policies in linking nations' business cycles across that exhibit a wide range of prior comovement levels. The Kolmogorov-Smirnov test statistic for differences between the distributions is significant at the one percent level, showing that these densities are significantly different by treaty status and time period.

The benefit of the kernel density estimate is the possibility to estimate different effects of BTTs across country-pairs with different observed levels of comovement; yet we sacrifice the ability to control for other covariates including decade fixed effects. This trade-off is reasonable in the context of the evidence in Sections 4.1 and 4.2 that other covariates and decade fixed effects, while often important in their own right, do not significantly impact our coefficient of interest for cyclical comovement - the effect of signing a BTT. ${ }^{25}$ Although decade fixed effects do not significantly impact the estimated effect of BTTs in the parametric analysis for cyclical comovement, one might nevertheless worry that some of the conclusions drawn from Figure 2 are simply due to the changing comovement across time that are disproportionately included in the pre or post period. To address such concerns we examined Figure 2 excluding the 2000's and found very similar results. ${ }^{26}$

\subsection{Alternative Definition of Comovement: HP Filter}

Up to this point we have focused our analysis on comovement as measured by the correlation GDP shocks between countries, where these shocks were estimated using our preferred UC model. Many previous studies have instead used band-pass filters, such as the HP filter (Hodrick \& Prescott, 1997), to estimate the cyclical component of nations' GDP series and to measure of comovement. The summary statistics in Table 1 demonstrates that there are substantial differences between

\footnotetext{
${ }^{25}$ While not reported in the paper, Column (1) of tables 2 and 3 are almost identical with and without decade fixed effects.

${ }^{26}$ The small hump on the right side of the post-treaty density of cyclical comovement disappears, but the general shift to the right remains, and the kernel densities are still significantly different (p-value: 0.016 ) across treaty status.
} 
measured comovement calculated from the UC model and HP filter. ${ }^{27}$ Thus, it is prudent to examine the robustness of the effects of fiscal policy across different measures of comovement. In this section, we consider the effect of BTTs with comovement measured as the correlation in business cycles obtained from an HP filter.

Table 5 reports the results from both the linear and GEE specifications where the dependent variable is the decade-long correlation in cyclical shocks estimated using the HP filter. In Columns (1)-(3) we sequentially introduce covariates and country-pair fixed effects in the linear model Columns (4)-(7) report estimates from the GEE model. We continue to find that BTTs exert a positive and significant effect on comovement across all columns. The effect of BTTs on comovement not only remains statistically significant when the HP filter is used to calculate comovement, but the quantitative magnitudes of the estimates from our preferred GEE specification remain approximately the same as when comovement was obtained from the UC model. In both cases, the effect of a new BTT is roughly one-and-a-half times larger than the effect of a one standard deviation increase in trade linkages. ${ }^{28}$ The robustness and quantitative similarity of the effects of BTTs across these various measure of comovement further support the conclusion that BTTs do indeed raise comovement between nations

Accounting for the boundedness of comovement using the GEE model matters substantially more when using an HP filter than it did when comovement was obtained from the UC model. This is likely due to the fact that there are substantially more observations near the upper bound when comovement is measured using the HP filter. Comparing our preferred linear model specification (Column (3)) to the comparable GEE model estimates (Column (6)), we see that the linear model produces an estimate on Treaty that is biased upwards by about half the standard deviation in the coefficient estimate, the effects of trade and GDP per capita differences are biased downward by approximately half a standard deviation, and the estimated effect of a currency union is biased about three standard deviations downward. ${ }^{29}$

\footnotetext{
${ }^{27}$ For all countries we set the smoothing parameter $\lambda$ for the HP filter to a value of 1600 .

${ }^{28}$ We note that it one cannot compare the estimated effects across specifications directly given the differences in the way the dependent variable is measured. However, we can compare the relative effects of say, Trade and Treaty, within each specification.

${ }^{29}$ Recall that to estimate the GEE model observations of comovement were rescaled - see equation (2). To compare the impacts direction one must compare the relative effects of standard deviations in variables.
} 


\section{Conclusion}

Many countries exhibit large correlations between shocks to their GDP series over time. We have carefully documented in this paper that BTTs increase the comovement of business cycles and shocks to output trends. This fact has several broader implications. Beginning with Mundell (1961), a large literature has argued that similarity in shocks to nations' GDP series is an important criterion for optimal currency areas. The potential for tax treaties to facilitate the transmission of output shocks across borders could make countries more suitable for currency union membership. This fact has obvious relevance to the European Economic and Monetary Union that is still debating fiscal policies with other member nations. On the other hand, greater international comovement means that a larger portion of the total fluctuations in a nations' GDP series may actually originate abroad. This can increase the strain on domestic policies - fiscal, monetary and commercial - to smooth volatility at home, since foreign shocks are outside their scope of influence. If greater international fiscal policy coordination can potentially weaken the ability of domestic policy to smooth volatility, there may be important deadweight loss implications. In either case, the linkages created by changes to global fiscal policies should not be ignored.

Our results highlighted that effects of BTTs are symmetric across nations whose GDP series tend to positively or negatively comove. Regardless of their prior level of comovement, we find evidence that BTTs raise the overall correlation between aggregate shocks. This fact is important in that it speaks to the potential efficacy of fiscal policy across a broad set of countries. We also found that tax treaties raise comovement between shocks to aggregate output trends in addition to creating linkages for business cycle transmission. Hence, the international investment and production linkages created by BTTs can have permanent consequences to nations GDP series.

\section{References}

Aguiar, M. \& Gopinath, G. (2007). Emerging market business cycles: The cycle is the trend. Journal of Political Economy, 115(1).

Baxter, M. \& King, R. G. (1999). Measuring business cycles: Approximate band-pass filters for economic time series. Review of Economics and Statistics, 81(4), 575-593. 
Baxter, M. \& Kouparitsas, M. A. (2005). Determinants of business cycle comovement: A robust analysis. Journal of Monetary Economics, 52(1), 113-57.

Blonigen, B. A., Oldenski, L., \& Sly, N. (2014). The differential effects of bilateral tax treaties. American Economic Journal: Economic Policy, 6(2), 1-18.

Blonigen, B. A., Piger, J., \& Sly, N. (2014). Comovement in GDP trends and cycles among trading partners. Journal of International Economics, forthcoming.

Boudoukh, J., Richardson, M., \& Whitelaw, R. F. (1994). Industry returns and the Fisher effect. Journal of Finance, 49(5), 1595-1615.

Burstein, A., Kurz, C., \& Tesar, L. L. (2008). Trade, production sharing and the international transmission of business cycles. Journal of Monetary Economics, 55, 775-795.

Calderon, C., Chong, A., \& Stein, E. (2007). Trade intensity and business cycle synchronization: Are developing countries different. Journal of International Economics, 71(1), 2-21.

Chisik, R. \& Davies, R. B. (2004). Asymmetric fdi and tax-treaty bargaining: theory and evidence. Journal of Public Economics, 88, 1119-1148.

Claessens, S. \& Forbesi, K. J. (2001). International Financial Contagion. Springer Science+Business Media New York.

Clark, P. K. (1987). The cyclical component of economic activity. Quarterly Journal of Economics, 102(4), 797-814.

Clark, T. E. \& van Wincoop, E. (2001). Borders and business cycles. Journal of International Economics, 55, 59-85.

Cogley, T. (1990). International evidence on the size of the random walk in output. Journal of Political Economy, 98, 501-18.

Cogley, T. (2001). Alternative definitions of the business cycle and their implications for business cycle models: A reply to Torben Mark Pedersen. Journal of Economic Dynamics and Control, 25(8), 1103-1107.

Cogley, T. \& Nason, J. M. (1995). Effects of the hodrick-prescott filter on trend and difference stationary time series: Implications for business cycle research. Journal of Economic Dynamics and Control, 19(1-2), 253-278.

Corsetti, G., Kuester, K., \& Müller, G. J. (2011). Floats, pegs and the transmission f fiscal policy. mimeo University of Cambridge.

Corsetti, G. \& Müller, G. J. (2006). Twin deficits: squaring theory, evidence and common sense. Economic Policy, 21 (48), 597-638.

Cravino, J. \& Levchenko, A. A. (2014). Multinational firms and international business cycle transmission. University of Michigan.

Davies, R. B., Norback, P.-J., \& Tekin-Koru, A. (2009). The effect of tax treaties on multinational firms: new evidence from micro-data. The World Economy, 32(1), 77-110. 
Devereux, M. B. \& Mansoorian, A. (1992). International fiscal policy coordination and economic growth. International Economic Review, 33(2), 249-68.

Doyle, B. M. \& Faust, J. (2005). Breaks in the variability and comovement of G-7 economic growth. Review of Economics and Statistics, 87(4), 721-740.

Easson, A. (2000). Do we still need tax treaties? Bulletin for International Fiscal Documentation, $54,619-625$.

Egger, P., Larch, M., Pfaffermayr, M., \& Winner, H. (2006). The impact of endogenous tax treaties on foreign direct investment: Theory and empirical evidence. Canadian Journal of Economics, $39(3), 901-931$.

Fernández-Val, I. (2009). Fixed effects estimation of structural parameters and marginal effects in panel probit models. Journal of Econometrics, 150, 71-85.

Feyrer, J. \& Shambaugh, J. (2012). Global savings and global investment: the transmission fiscal shocks. American Economic Journal: Economic Policy, 4(2), 95-114.

Frankel, J. A. \& Rose, A. K. (1998). The endogeneity of optimum currency area criteria. The Economic Journal, 108(449), 1009-1025.

Frenkel, J. A. \& Razin, A. (1986). Fiscal policies in the world economy. Journal of Political Economy, 94(3), 564-94.

Guerrieri, L., Iacoviello, M., \& Minetti, R. (2012). Banks, sovereign debt, and the international transmission of business cycles. In F. Giavazzi \& K. D. West (Eds.), International Seminar on Macroeconomics (ISOM). NBER.

Harvey, A. C. (1985). Trends and cycles in macroeconomic time series. Journal of Business and Economic Statistics, 3(3), 216-227.

Harvey, A. C. \& Jaeger, A. (1993). Stylized facts and the business cycle. Journal of Applied Econometrics, 8(3), 231-247.

Hodrick, R. J. \& Prescott, E. C. (1997). Postwar U.S. business cycles: An empirical investigation. Journal of Money, Credit and Banking, 29(1), 1-16.

Imbs, J. (2004). Trade, finance specialization and synchronization. Review of Economics and Statistics, 86(3), 723-734.

Imbs, J. \& Wacziarg, R. (2003). Stages of diversification. American Economic Review, 93(1), $63-86$.

Karolyi, G. A. \& Stulz, R. M. (1996). Why do markets move together? An investigation of U.S.-Japan stock return comovements. Journal of Finance, 51(3), 951-86.

Kawano, L. \& Slemrod, J. (2012). The effect of tax rates and tax bases on corporate tax revenues: Estimates with new measures of the corporate tax base. NBER working paper 18440.

Keen, M. (2014). imfdirect: Fixing international corporate taxation - not just a problem for advanced economies. 
Kleinert, J., Martin, J., \& Toubal, F. (2014). The few leading the many: Foreign affiliates and business cycle comovement. American Economic Journal: Macroeconomics, forthcoming.

Kose, M. A., Otrok, C., \& Prasad, E. S. (2012). Global business cycles: Converging or decoupling. International Economic Review, 53(2), 511-538.

Kose, M. A., Otrok, C., \& Whiteman, C. (2008). Understanding the evolution of world business cycles. Journal of International Economics, 75(1), 110-130.

Kose, M. A., Prasad, E. S., \& Terrones, M. E. (2003). How does globalization affect the synchronization of business cycles? American Economic Review, 93(2), 57-62.

Levchenko, A. \& di Giovanni, J. (2010). Putting the parts together: Trade, vertical linkages and business cycle comovement. American Economic Journal: Macroeconomics, 2(2), 95-124.

Morley, J. C., Nelson, C. R., \& Zivot, E. (2003). Why are the Beveridge-Nelson and UnobservedComponents decompositions of GDP so different? Review of Economics and Statistics, 85(2), 235-243.

Mundell, R. (1961). A theory of optimum currency areas. American Economic Review, 85(3), $615-23$.

Murray, C. J. (2003). Cyclical properties of Baxter-King filtered time series. Review of Economics and Statistics, 85(2), 472-476.

Papke, L. E. \& Wooldridge, J. M. (1996). Econometric methods for fractional response variables with an application to 401(k) plan participation rates. Journal of Applied Econometrics, 11, 619-632.

Papke, L. E. \& Wooldridge, J. M. (2008). Panel data methods for fractional response variables with an application to test pass rates. Journal of Econometrics, 145, 121-133.

Pedersen, T. M. (2001). The hodrick-prescott filter, the slutzky effect, and the distortionary effect of filters. Journal of Economic Dynamics and Control, 25(8), 1081-1101.

Rose, A. K. \& Engel, C. (2002). Currency unions and international integration. Journal of Money, Credit and Banking, 34(4), 2002.

Seegert, N. (2012). Optimal taxation with volatility: A theoretical and empirical decomposition. mimeo Univeristy of Michigan.

Stock, J. H. \& Watson, M. W. (2005). Understanding changes in international business cycle dynamics. Journal of the European Economics Association, 3(5), 968-1006.

Watson, M. W. (1986). Univariate detrending methods with stochastic trends. Journal of Monetary Economics, 18(1), 49-75.

Wooldridge, J. M. (2010). Econometric Analysis of Cross Section and Panel Data (2nd Edition). Cambridge, MA: MIT Press. 


\section{Figure 1: Rolling 10-Year Comovement by Quarter}

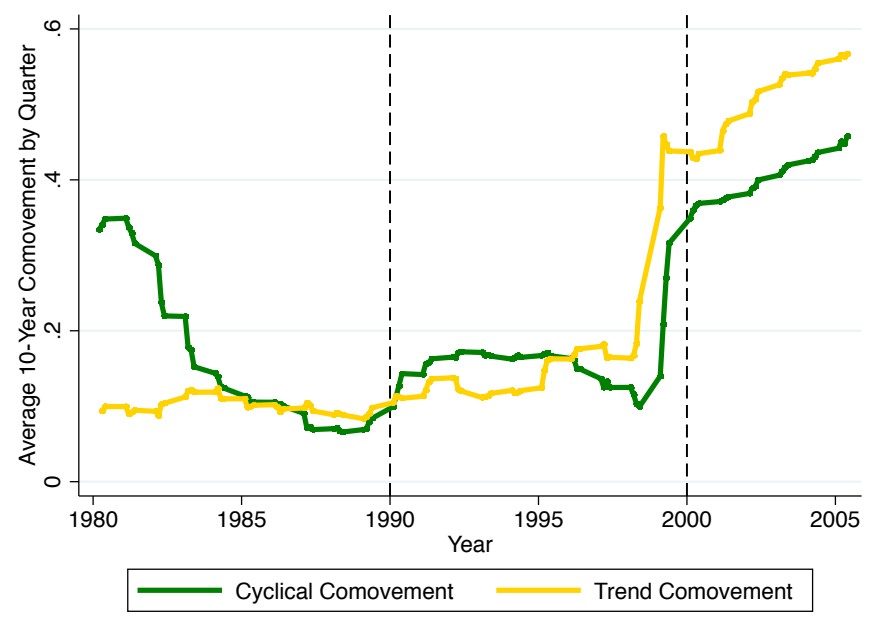

This figure plots the average decade-long comovement in cyclical and trend shocks to GDP across all country-pairs by quarter. For example, the comovement plotted for the first quarter of 1982 is the comovement from the first quarter of 1982 to the first quarter of 1992. After 2001, comovement is calculated as comovement from a given point in time through the end of the sample (2010 Q4). For example, in 2003, comovement is only calculated over an eight-year horizon.

Figure 2: Kernal Density Estimates of Cyclical Comovement Before and After Treaty in Force

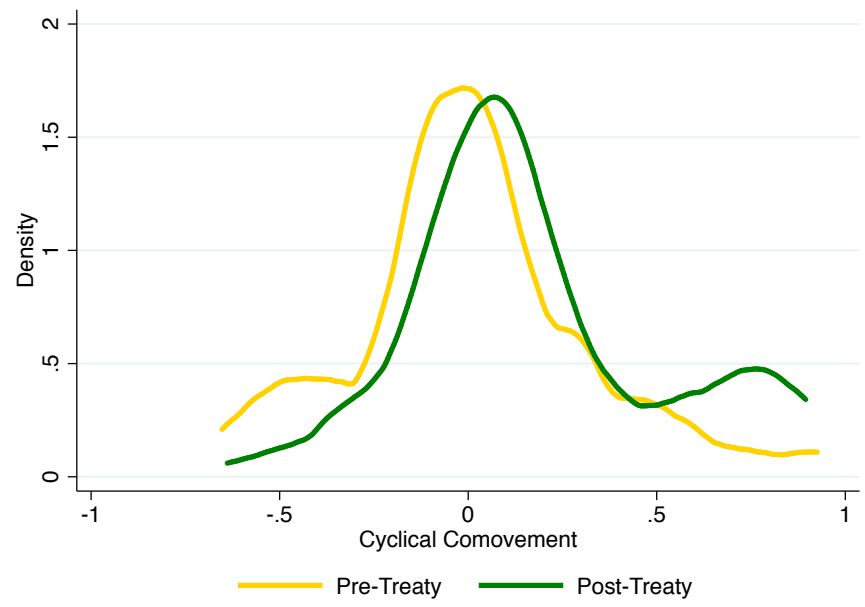

This figure plots the kernel density estimate of decade cyclical comovement before (yellow line) and after (green line) a treaty is put into force. The bandwidth is 0.092. An Epanechnikov kernel is used. The p-value of the

Kolmogorov-Smirnov statistic comparing these two densities is 0.001 . 
Table 1: Summary Statistics

\begin{tabular}{lcc}
\hline \multicolumn{1}{c}{ Variable } & Mean & Std. Dev. \\
\hline$\rho_{\text {cycle } U C}$ & 0.248 & 0.416 \\
$\tilde{\rho}_{\text {cycle } U C}$ & 0.624 & 0.208 \\
$\rho_{\text {cycle } H P}$ & 0.360 & 0.370 \\
$\tilde{\rho}_{\text {cycle } H P}$ ( $)$ & 0.680 & 0.185 \\
$\rho_{\text {trend }, U C}$ & 0.211 & 0.242 \\
$\tilde{\rho}_{\text {trend }, U C}$ & 0.606 & 0.121 \\
Treaty & 0.860 & 0.315 \\
Trade & 0.223 & 0.525 \\
GDP Per Capita Diffs & 0.063 & 0.075 \\
Corporate Tax Rate Diffs & 7.607 & 7.744 \\
Currency Union & 0.044 & 0.206 \\
G7 & 0.567 & 0.496 \\
Bilateral Investment Treaty & 0.055 & 0.214 \\
Free Trade Agreement & 0.037 & 0.182 \\
EU Customs Union & 0.433 & 0.496 \\
Observations & 630 & \\
\hline
\end{tabular}


Table 2: Cyclical Comovement with Linear Response Model

\begin{tabular}{|c|c|c|c|c|c|c|}
\hline & $(1)$ & $(2)$ & $(3)$ & $(4)$ & $(5)$ & $(6)$ \\
\hline Treaty & $\begin{array}{l}0.277^{* * *} \\
(0.051)\end{array}$ & $\begin{array}{l}0.163^{* * *} \\
(0.051)\end{array}$ & $\begin{array}{l}0.197^{* * *} \\
(0.054)\end{array}$ & $\begin{array}{c}0.227^{* *} \\
(0.096)\end{array}$ & $\begin{array}{c}0.206^{* *} \\
(0.088)\end{array}$ & $\begin{array}{l}0.230^{* *} \\
(0.107)\end{array}$ \\
\hline Trade & & $\begin{array}{l}0.105^{* * *} \\
(0.034)\end{array}$ & $\begin{array}{l}0.110^{* * *} \\
(0.034)\end{array}$ & & $\begin{array}{l}0.225^{* *} \\
(0.107)\end{array}$ & $\begin{array}{c}0.101 \\
(0.212)\end{array}$ \\
\hline GDP Per Capita Diffs & & $\begin{array}{c}-0.749^{* * *} \\
(0.188)\end{array}$ & $\begin{array}{c}-0.635^{* * *} \\
(0.201)\end{array}$ & & $\begin{array}{c}-0.267 \\
(0.239)\end{array}$ & $\begin{array}{c}-2.390^{* * *} \\
(0.411)\end{array}$ \\
\hline Corporate Tax Rate Diffs & & $\begin{array}{c}0.003 \\
(0.002)\end{array}$ & $\begin{array}{c}0.002 \\
(0.003)\end{array}$ & & $\begin{array}{c}0.008^{* *} \\
(0.004)\end{array}$ & $\begin{array}{l}0.014^{* * *} \\
(0.005)\end{array}$ \\
\hline Currency Union & & $\begin{array}{l}0.188^{* * *} \\
(0.065)\end{array}$ & $\begin{array}{c}0.129^{*} \\
(0.069)\end{array}$ & & $\begin{array}{r}-0.115^{*} \\
(0.066)\end{array}$ & \\
\hline G7 & & $\begin{array}{l}0.117^{* * *} \\
(0.042)\end{array}$ & $\begin{array}{l}0.112^{* * *} \\
(0.042)\end{array}$ & & & \\
\hline 1990's FE & $\begin{array}{c}-0.219^{* * *} \\
(0.032)\end{array}$ & & $\begin{array}{c}-0.224^{* * *} \\
(0.033)\end{array}$ & $\begin{array}{c}-0.213^{* * *} \\
(0.032)\end{array}$ & $\begin{array}{c}-0.204^{* * *} \\
(0.036)\end{array}$ & $\begin{array}{c}-0.233^{* * *} \\
(0.038)\end{array}$ \\
\hline 2000's FE & $\begin{array}{c}0.019 \\
(0.030)\end{array}$ & & $\begin{array}{r}-0.037 \\
(0.038)\end{array}$ & $\begin{array}{c}0.029 \\
(0.030)\end{array}$ & $\begin{array}{c}0.045 \\
(0.042)\end{array}$ & \\
\hline Country-Pair FE & No & No & No & Yes & Yes & Yes \\
\hline Include 2000's & Yes & Yes & Yes & Yes & Yes & No \\
\hline Observations & 630 & 630 & 630 & 630 & 630 & 420 \\
\hline Country-Pairs & 210 & 210 & 210 & 210 & 210 & 210 \\
\hline
\end{tabular}

significance at the 5 percent level, and ${ }^{*}$ indicates significance at the 10 percent level. 
Table 3: Cyclical Comovement with Fractional Response Model

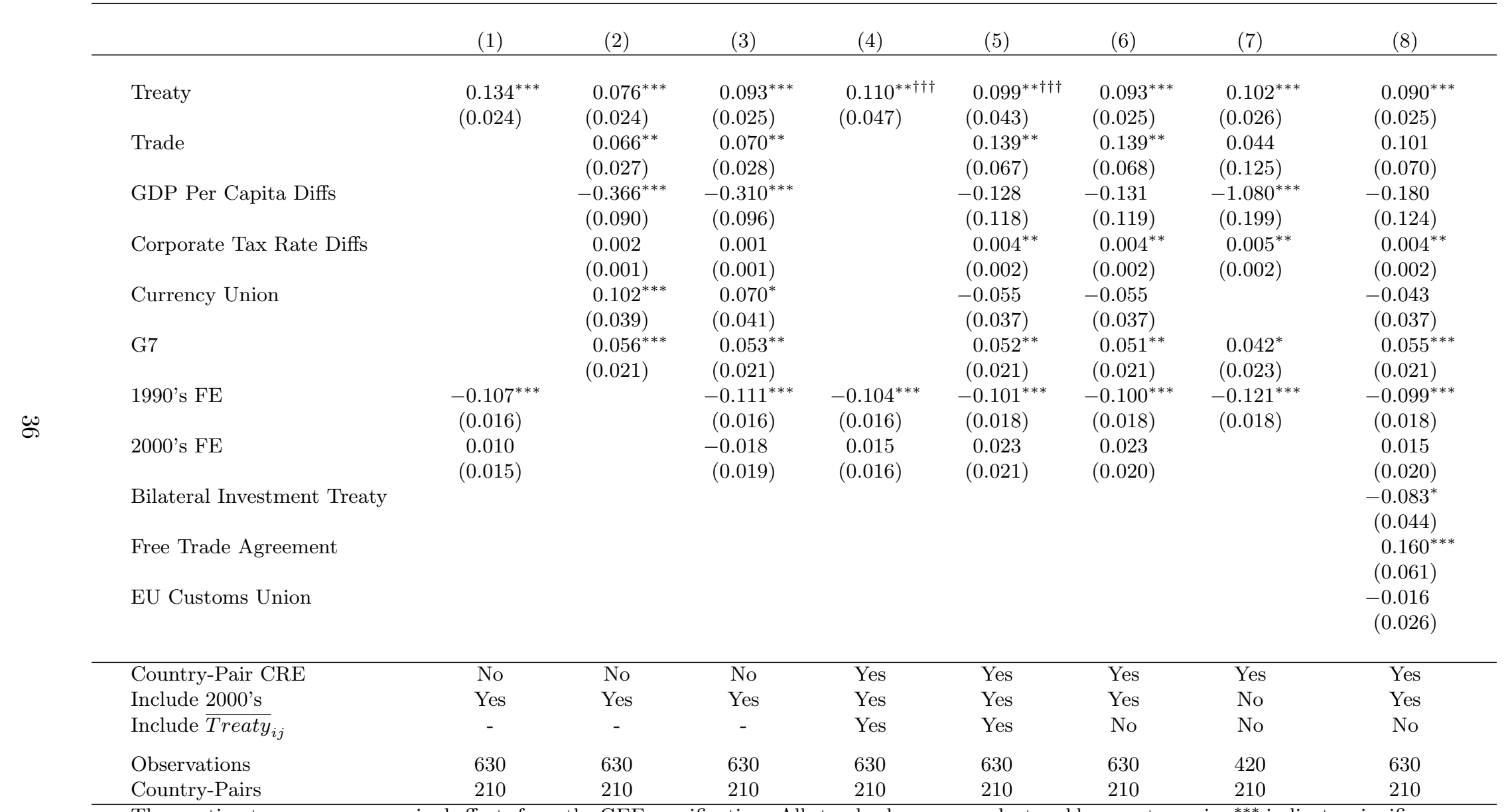

These estimates are mean marginal effects from the GEE specification. All standard errors are clustered by country-pair. ${ }^{* * *}$ indicates significance at the 1 percent level, ${ }^{* *}$ indicates significance at the 5 percent level, and ${ }^{*}$ indicates significance at the 10 percent level. ${ }^{\dagger \dagger}{ }^{T}$ The mean value for each country-pair of this variable is included in this regression despite its mechanical multicollinearity with the variable itself. The variable and its mean are jointly significant at the 1 percent level. 
Table 4: Trend Comovement with Fractional Response Model

\begin{tabular}{|c|c|c|c|c|c|c|c|c|}
\hline & $(1)$ & $(2)$ & $(3)$ & (4) & $(5)$ & (6) & (7) & (8) \\
\hline Treaty & $\begin{array}{c}0.029^{* *} \\
(0.012)\end{array}$ & $\begin{array}{l}0.053^{* * *} \\
(0.128)\end{array}$ & $\begin{array}{c}0.031^{* *} \\
(0.013)\end{array}$ & $\begin{array}{l}0.035^{* \dagger \dagger \dagger} \\
(0.019)\end{array}$ & $\begin{array}{l}0.029^{\dagger \dagger \dagger} \\
(0.018)\end{array}$ & $\begin{array}{c}0.026^{* *} \\
(0.012)\end{array}$ & $\begin{array}{c}0.026^{* *} \\
(0.012)\end{array}$ & $\begin{array}{c}0.021^{*} \\
(0.013)\end{array}$ \\
\hline Trade & & $\begin{array}{c}0.012 \\
(0.010)\end{array}$ & $\begin{array}{c}0.014 \\
(0.010)\end{array}$ & & $\begin{array}{c}-0.024 \\
(0.016)\end{array}$ & $\begin{array}{c}-0.023 \\
(0.016)\end{array}$ & $\begin{array}{c}-0.035 \\
(0.047)\end{array}$ & $\begin{array}{c}-0.040^{* *} \\
(0.019)\end{array}$ \\
\hline GDP Per Capita Diffs & & $\begin{array}{c}-0.441^{* * *} \\
(0.063)\end{array}$ & $\begin{array}{c}-0.144^{* *} \\
(0.059)\end{array}$ & & $\begin{array}{c}-0.181^{* * *} \\
(0.069)\end{array}$ & $\begin{array}{c}-0.183^{* * *} \\
(0.069)\end{array}$ & $\begin{array}{c}-0.242^{* *} \\
(0.107)\end{array}$ & $\begin{array}{c}-0.167^{* *} \\
(0.073)\end{array}$ \\
\hline Corporate Tax Rate Diffs & & $\begin{array}{c}-0.001^{* *} \\
(0.001)\end{array}$ & $\begin{array}{c}-0.001^{* *} \\
(0.000)\end{array}$ & & $\begin{array}{c}-0.002^{* *} \\
(0.001)\end{array}$ & $\begin{array}{c}-0.002^{* *} \\
(0.001)\end{array}$ & $\begin{array}{r}-0.002^{*} \\
(0.001)\end{array}$ & $\begin{array}{c}-0.002^{* *} \\
(0.001)\end{array}$ \\
\hline Currency Union & & $\begin{array}{l}0.174^{* * *} \\
(0.017)\end{array}$ & $\begin{array}{l}0.104^{* * *} \\
(0.017)\end{array}$ & & $\begin{array}{c}0.057^{* *} \\
(0.024)\end{array}$ & $\begin{array}{c}0.057^{* *} \\
(0.024)\end{array}$ & & $\begin{array}{l}0.064^{* * *} \\
(0.024)\end{array}$ \\
\hline G7 & & $\begin{array}{c}-0.027^{* * *} \\
(0.009)\end{array}$ & $\begin{array}{c}-0.019^{* *} \\
(0.008)\end{array}$ & & $\begin{array}{c}-0.018^{* *} \\
(0.008)\end{array}$ & $\begin{array}{c}-0.018^{* *} \\
(0.008)\end{array}$ & $\begin{array}{c}-0.030^{* * *} \\
(0.010)\end{array}$ & $\begin{array}{c}-0.012 \\
(0.008)\end{array}$ \\
\hline 1990's FE & $\begin{array}{c}-0.009 \\
(0.008)\end{array}$ & & $\begin{array}{r}-0.016^{*} \\
(0.009)\end{array}$ & $\begin{array}{c}-0.009 \\
(0.009)\end{array}$ & $\begin{array}{r}-0.018^{*} \\
(0.010)\end{array}$ & $\begin{array}{r}-0.018^{*} \\
(0.009)\end{array}$ & $\begin{array}{r}-0.020^{*} \\
(0.010)\end{array}$ & $\begin{array}{r}-0.017^{*} \\
(0.009)\end{array}$ \\
\hline 2000's FE & $\begin{array}{l}0.146^{* * *} \\
(0.009)\end{array}$ & & $\begin{array}{l}0.114^{* * *} \\
(0.011)\end{array}$ & $\begin{array}{l}0.144^{* * *} \\
(0.010)\end{array}$ & $\begin{array}{l}0.115^{* * *} \\
(0.014)\end{array}$ & $\begin{array}{l}0.115^{* * *} \\
(0.013)\end{array}$ & & $\begin{array}{l}0.111^{* * *} \\
(0.013)\end{array}$ \\
\hline Bilateral Investment Treaty & & & & & & & & $\begin{array}{c}0.002 \\
(0.024)\end{array}$ \\
\hline Free Trade Agreement & & & & & & & & $\begin{array}{l}0.062^{* * *} \\
(0.024)\end{array}$ \\
\hline EU Customs Union & & & & & & & & $\begin{array}{l}0.024^{* * *} \\
(0.009)\end{array}$ \\
\hline Country-Pair CRE & No & No & No & Yes & Yes & Yes & Yes & Yes \\
\hline Include 2000's & Yes & Yes & Yes & Yes & Yes & Yes & No & Yes \\
\hline Include $\overline{\text { Treaty }}_{i j}$ & - & - & - & Yes & Yes & No & No & No \\
\hline Observations & 630 & 630 & 630 & 630 & 630 & 630 & 420 & 630 \\
\hline Country-Pairs & 210 & 210 & 210 & 210 & 210 & 210 & 210 & 210 \\
\hline
\end{tabular}

These estimates are mean marginal effects from the GEE specification. All standard errors are clustered by country-pair. ${ }^{* * *}$ indicates significance at the 1 percent level, ${ }^{* *}$ indicates significance at the 5 percent level, and ${ }^{*}$ indicates significance at the 10 percent level. ${ }^{\dagger \dagger \dagger}$ The mean value for each country-pair of this variable is included in this regression despite its mechanical multicollinearity with the variable itself. The variable and its mean are jointly significant at the 1 percent level. 
Table 5: Heterogeneous Responses to Treaty

\begin{tabular}{|c|c|c|c|c|c|c|}
\hline & \multicolumn{2}{|c|}{$(1)$} & \multicolumn{2}{|c|}{$(2)$} & \multicolumn{2}{|c|}{$(3)$} \\
\hline & Non-G7 & G7 & Non-G7 & G7 & Non-G7 & G7 \\
\hline \multirow[b]{2}{*}{ Treaty } & \multicolumn{6}{|c|}{ Cyclical Comovement } \\
\hline & $\begin{array}{c}0.055 \\
(0.036)\end{array}$ & $\begin{array}{l}0.190^{* * *} \\
(0.033)\end{array}$ & $\begin{array}{c}0.031 \\
(0.036)\end{array}$ & $\begin{array}{l}0.163^{* * *} \\
(0.034)\end{array}$ & $\begin{array}{c}0.049 \\
(0.033)\end{array}$ & $\begin{array}{c}0.153^{\text {*** }} \\
(0.040)\end{array}$ \\
\hline \multirow[b]{2}{*}{ Treaty } & \multicolumn{6}{|c|}{ Trend Comovement } \\
\hline & $\begin{array}{l}0.049^{* * *} \\
(0.019)\end{array}$ & $\begin{array}{c}0.012 \\
(0.012)\end{array}$ & $\begin{array}{c}0.047^{* *} \\
(0.020)\end{array}$ & $\begin{array}{c}0.008 \\
(0.012)\end{array}$ & $\begin{array}{c}0.070^{* *} \\
(0.029)\end{array}$ & $\begin{array}{c}0.010 \\
(0.021)\end{array}$ \\
\hline Covariates & No & No & Yes & Yes & Yes & Yes \\
\hline Decade FE & Yes & Yes & Yes & Yes & Yes & Yes \\
\hline Country-Pair CRE & No & No & No & No & Yes & Yes \\
\hline Include 2000's & Yes & Yes & Yes & Yes & Yes & Yes \\
\hline Include $\overline{\text { Treaty }}_{i j}$ & Yes & Yes & Yes & Yes & Yes & Yes \\
\hline Observations & 273 & 357 & 273 & 357 & 273 & 357 \\
\hline Country-Pairs & 91 & 119 & 91 & 119 & 91 & 119 \\
\hline
\end{tabular}

These estimates are mean marginal effects from the GEE specification. All standard errors are clustered by countrypair. ${ }^{* * *}$ indicates significance at the 1 percent level, ${ }^{* *}$ indicates significance at the 5 percent level, and ${ }^{*}$ indicates significance at the 10 percent level. A pair is considered a G7 pair in this table if at least one country is part of the G7. When covariates are included, the covariates from Table 3 Column (8) are used. 
Table 6: Cyclical Comovement with HP Filter

\begin{tabular}{|c|c|c|c|c|c|c|c|}
\hline & $(1)$ & $(2)$ & $(3)$ & $(4)$ & $(5)$ & $(6)$ & $(7)$ \\
\hline & \multicolumn{3}{|c|}{ Linear Model } & \multicolumn{4}{|c|}{ Fractional Response Model } \\
\hline Treaty & $\begin{array}{l}0.240^{* * *} \\
(0.042)\end{array}$ & $\begin{array}{l}0.210^{* * *} \\
(0.041)\end{array}$ & $\begin{array}{c}0.171^{* *} \\
(0.067)\end{array}$ & $\begin{array}{l}0.108^{* * *} \\
(0.018)\end{array}$ & $\begin{array}{l}0.092^{* * *} \\
(0.018)\end{array}$ & $\begin{array}{l}0.068^{* * \dagger \dagger \dagger} \\
(0.033)\end{array}$ & $\begin{array}{l}0.081^{* * *} \\
(0.018)\end{array}$ \\
\hline Trade & & $\begin{array}{c}0.035 \\
(0.029)\end{array}$ & $\begin{array}{c}0.123 \\
(0.076)\end{array}$ & & $\begin{array}{c}0.021 \\
(0.018)\end{array}$ & $\begin{array}{c}0.081^{*} \\
(0.042)\end{array}$ & $\begin{array}{c}0.081^{*} \\
(0.043)\end{array}$ \\
\hline GDP Per Capita Diffs & & $\begin{array}{c}-0.558^{* * *} \\
(0.195)\end{array}$ & $\begin{array}{r}-0.353^{*} \\
(0.205)\end{array}$ & & $\begin{array}{c}-0.240^{* * *} \\
(0.084)\end{array}$ & $\begin{array}{c}-0.138 \\
(0.099)\end{array}$ & $\begin{array}{c}-0.131 \\
(0.099)\end{array}$ \\
\hline Corporate Tax Rate Diffs & & $\begin{array}{c}-0.000 \\
(0.002)\end{array}$ & $\begin{array}{c}-0.010^{* * *} \\
(0.003)\end{array}$ & & $\begin{array}{c}-0.000 \\
(0.001)\end{array}$ & $\begin{array}{c}-0.005^{* * *} \\
(0.002)\end{array}$ & $\begin{array}{c}-0.005^{* * *} \\
(0.002)\end{array}$ \\
\hline Currency Union & & $\begin{array}{l}0.169^{* * *} \\
(0.024)\end{array}$ & $\begin{array}{c}0.006 \\
(0.045)\end{array}$ & & $\begin{array}{l}0.153^{* * *} \\
(0.020)\end{array}$ & $\begin{array}{l}0.078^{* * *} \\
(0.027)\end{array}$ & $\begin{array}{l}0.078^{* * *} \\
(0.027)\end{array}$ \\
\hline G7 & & $\begin{array}{c}0.036 \\
(0.028)\end{array}$ & & & $\begin{array}{c}0.019 \\
(0.014)\end{array}$ & $\begin{array}{c}0.019 \\
(0.014)\end{array}$ & $\begin{array}{c}0.020 \\
(0.014)\end{array}$ \\
\hline 1990's FE & $\begin{array}{c}-0.050^{* *} \\
(0.025)\end{array}$ & $\begin{array}{c}-0.062^{* *} \\
(0.025)\end{array}$ & $\begin{array}{c}-0.085^{* * *} \\
(0.026)\end{array}$ & $\begin{array}{c}-0.022^{* *} \\
(0.011)\end{array}$ & $\begin{array}{c}-0.027^{* *} \\
(0.011)\end{array}$ & $\begin{array}{c}-0.039^{* * *} \\
(0.012)\end{array}$ & $\begin{array}{c}-0.040^{* * *} \\
(0.011)\end{array}$ \\
\hline 2000's FE & $\begin{array}{l}0.420^{* * *} \\
(0.028)\end{array}$ & $\begin{array}{l}0.351^{\text {*** }} \\
(0.032)\end{array}$ & $\begin{array}{l}0.348^{* * *} \\
(0.037)\end{array}$ & $\begin{array}{l}0.223^{* * *} \\
(0.015)\end{array}$ & $\begin{array}{l}0.187^{* * *} \\
(0.016)\end{array}$ & $\begin{array}{l}0.184^{* * *} \\
(0.019)\end{array}$ & $\begin{array}{l}0.182^{* * *} \\
(0.018)\end{array}$ \\
\hline Country-Pair FE/CRE & No & No & Yes & No & No & Yes & Yes \\
\hline Include $\overline{\text { Treaty }}_{i j}$ & - & - & - & No & No & Yes & No \\
\hline Include 2000's & Yes & Yes & Yes & Yes & Yes & Yes & Yes \\
\hline Observations & 630 & 630 & 630 & 630 & 630 & 630 & 630 \\
\hline Country-Pairs & 210 & 210 & 210 & 210 & 210 & 210 & 210 \\
\hline
\end{tabular}

All standard errors are clustered by country-pair. ${ }^{\dagger \dagger}$ The mean value for each country-pair of this variable is included in this regression despite its mechanical multicollinearity with the variable itself. The variable and its mean are jointly significant at the 1 percent level. 


\section{Appendix}

Table A.1: New Treaties in Force by Year

\begin{tabular}{|c|c|c|c|}
\hline Country-Pair & Year in Force & Country-Pair & Year in Force \\
\hline Australia-Sweden & 1981 & Spain-United States & 1990 \\
\hline Australia-Denmark & 1981 & Australia-Spain & 1992 \\
\hline Australia-Switzerland & 1981 & Canada-Mexico & 1992 \\
\hline Finland-Korea & 1981 & France-Mexico & 1992 \\
\hline France-Norway & 1981 & Italy-Korea & 1992 \\
\hline France-Korea & 1981 & Mexico-Sweden & 1992 \\
\hline Korea-Netherlands & 1981 & Germany-Mexico & 1993 \\
\hline Korea-Switzerland & 1981 & Mexico-United States & 1993 \\
\hline Finland-Germany & 1982 & Korea-Spain & 1994 \\
\hline Germany-Portugal & 1982 & Mexico-Netherlands & 1994 \\
\hline Korea-Sweden & 1982 & Mexico-United Kingdom & 1994 \\
\hline Australia-Norway & 1983 & Mexico-Switzerland & 1994 \\
\hline Denmark-Italy & 1983 & Mexico-Spain & 1994 \\
\hline Finland-Italy & 1983 & Italy-Netherlands & 1995 \\
\hline Italy-Portugal & 1983 & Korea-Mexico & 1995 \\
\hline Italy-Sweden & 1983 & Portugal-United States & 1995 \\
\hline Japan-Sweden & 1983 & Japan-Mexico & 1996 \\
\hline Korea-New Zealand & 1983 & Mexico-Norway & 1996 \\
\hline New Zealand-Belgium & 1983 & Denmark-Mexico & 1997 \\
\hline New Zealand-Norway & 1983 & Denmark-United Kingdom & 1997 \\
\hline Australia-Korea & 1984 & Korea-Portugal & 1997 \\
\hline Canada-Sweden & 1984 & Mexico-Belgium & 1997 \\
\hline Finland-New Zealand & 1984 & Finland-Mexico & 1998 \\
\hline Korea-Norway & 1984 & Austria-Spain & 1999 \\
\hline Australia-Italy & 1985 & Netherlands-Portugal & 2000 \\
\hline Austria-Italy & 1985 & Canada-Portugal & 2001 \\
\hline Australia-Finland & 1986 & Mexico-Portugal & 2001 \\
\hline Austria-Korea & 1987 & Australia-Mexico & 2003 \\
\hline Denmark-Norway & 1987 & Denmark-Portugal & 2003 \\
\hline Denmark-Finland & 1987 & Portugal-Sweden & 2003 \\
\hline Denmark-Sweden & 1987 & Austria-Mexico & 2005 \\
\hline Finland-Norway & 1987 & New Zealand-Spain & 2006 \\
\hline Finland-Sweden & 1987 & Austria-New Zealand & 2007 \\
\hline Italy-Norway & 1987 & Austria-Norway & 2007 \\
\hline Norway-Sweden & 1987 & Mexico-New Zealand & 2007 \\
\hline Australia-Austria & 1988 & & \\
\hline
\end{tabular}

